\title{
To Shape a Silence While Breaking it: Toni Morrison's the Bluest Eye
}

\section{Asst. Prof. Isra HashimTaher(Ph.D.)}

E-mail: israh@ coart.uobaghdad.iq University of Baghdad, College of Arts, Department of English, Baghdad, Iraq.

(Received on 8/4/2018: Accepted on 28/6/2018)

\section{DOI: https://doi.org/10.36586/jcl.2.2019.0.39.0071}

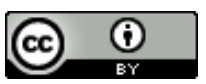

This work is licensed under a Creative Commons Attribution 4.0 International License.

\begin{abstract}
Toni Morrison (1931-), the first African-American winner of Noble Prize in literature (1993) and the winner of the 1988 Pulitzer Prize for fiction, regards herself as the historian of African-American people. She does not think of her writings as literature but as a sacred book dedicated to explore the interior lives of blacks. She creates history by disregarding European standards and the white man's view of African- Americans. She adopts her people's point of view, invests their heritage, voices their pains and uses their vernacular. She even writes to a black audience. She establishes the black novel by depicting the blackness of American literature. In choosing to write about the past, she is not being didactic like other writers, she is rather visionary.In choosing "to rip that veil drawn
\end{abstract}


over 'proceedings too terrible to relate' " she breaks the silence by discussing subjects like rape and incest, that is why her first novel ,The Bluest Eye (1970), can be taken as an example of Young Adult Literature, a literature that addresses the challenges and problems the teens and adolescents face while coming of age.

Published in 1970s and set in the Ohio of 1940s, the novel focuses on the personal experience of a young black girl, Pecola Breedlove, who because of her ugliness and invisibility, prays to have blue eyes, which she thinks, will provide her with beauty and love. The novel ends with her hallucinations after being raped by her father and after she presumably thinks she has blue eyes. The paper argues that in The Bluest Eye Morrison accomplishes a twofold task: contributing to Young Adult Literature while emphasizing that "the demonization of a whole race could take root inside the most delicate member of society: a child."

Key words: Morrison, The Bluest Eye, history, Young Adult Literature.

\section{Toni Morrison's the Bluest Eye}

Ever since the publication of her first novel, Morrison's workhas always handled a heavy load. Her books are saturated with history and people who are left out of history. Morrison's project is obvious: it is history that extends through eleven novels. This is the project clearly understood and accepted even by her opponents. But then there is the other mission, the less obvious one, the one which Morrison ventures to undertake as a former member of the working class, as a woman, and as a minority: she implies in all of her books that: 
blackness isn't a commodity; it isn't inherently political; it is the race of a people who are varied and complicated. This is where her works become less of a history and more of a liturgy, still stretching across geographies and time... It is a project that, has allowed Morrison to play with language, to take chances with how stories unravel and to consistently resist the demand to create an empirical understanding of black life in America. Instead, she makes black life complex, fantastic and heroic, despite its devaluation (Ghansah).

Throughout her body of work, Toni Morrison has been deeply engaged with the politics and ethics of visuality. Morrison's interest in visuality stems from her desire to represent the African- Americans' plight, a plight that she describes as "grotesque" and which she later explains in these terms: "my people are being devoured." Morrison recognizes that America's racial past and its ongoing legacyhave been rendered largely invisible in American culture, througha process of erasure and forgettingthough its effects remain largely felt and influence the lives of contemporary Americans, both black and white(Laflen 22). She has also suggested in Site of Memory that slave narratives, narratives by free exslaves who narrate their struggle with slavery and their ultimate success in gaining their freedom, highly impacted this process of erasure. " In shaping the experience to make it palatable to those who were in a position to alleviate it, they were silent about many things, and they "forgot" many other things"(109-10). Then she declared her duty as a novelist:

This peculiar phase of Slavery has generally been kept veiled; but the public ought to be made acquainted with its monstrous features...My job becomes how to rip that veil drawn over "proceedings too terrible to 
relate." The exercise is also critical for any person whoisblack, or who belongs to any marginalized category, for, historically, we were seldom invited to participate in the discourse even when wewere its topic. Moving that veil aside requires, therefore, certain things. First of all, I must trust my own recollections. I must also depend onthe recollections of others. Thus memory weighs heavily in what I write, in how I begin and in what I find to be significant...memories and recollections ... [that] give me ...access to the unwritten interior life of these people (113).

In The Bluest Eye, Morrison relied on one of her childhood experiences to examine what could happen to "the most vulnerable member" of a community, a black female child, at a time before black became beautiful in America. In an "afterword" she added to the novel in 1993, Morrison described how she came to build her novel on the story of her childhood classmate who expressed a desire for blue eyes, an idea that struck Morrison as a form of violence, namely, mutilation, and her confusion about how the classmate had come to prefer them to her own dark eyes. This childhood experience informed Morrison's subsequent engagement with the Black Arts movement in the 1960s, whose members adopted the motto of black is beautiful as a means to encourage black people to regain their beauty. Though Morrison found these assertions inspiring, she also questioned why it was necessary for black people to reclaim blackness; and why they had come to accept the dominant view of beauty? (Laflen22)

Since the publication of her first novel, Morrison has conducted what she terms a " 'literary archaeology' of the lives of African-Americans" (qtd. in Madden ). In heressay "Rootedness: The Ancestor as Foundation" 
Toni Morrison established the terms that would define her writings. She noted that the novel "has always functioned for the class or the group that wrote it." The novel that concerned itself with black Americans was remarkable and needed, she wrote, because it accomplished "certain very strong functions," now that "parents don't sit around and tell their children those classical, mythological archetypal stories that we heard years ago." The black novel was important because it could "suggest what the conflicts are, what the problems are, not necessarily as a means of solving them but as a way of recording and reflecting them. 'What I'm interested in is writing without the gaze, without the white gaze' "(Ghansah).

Morrison's The Bluest Eye is highly influenced by the Black Power/Liberation era and the Black Arts Aesthetics Movement (BAAM) of the 1960s, especially their questioning of hegemonic constructions of Western cultural ideas and ideals. They were particularly concerned with concepts, ideals, and systemic structures that worked to diminish black people. This novel further operates as a response to the challenge among Black Aesthetic artists to question and resist such delimiting influences. Morrison's The Bluest Eye is one example of numberless works at the time which aim at reconstructing a cultural context out of which African American people could operate and toward creating as much as possible" a reconstituted identity" (Jimoh).

The Black Arts Aesthetics Movement coincided with the emergence of Young Adult Literature. Over the last fifty years, experts have tried to define Young Adult (YA) Literature. Young adult literature, adolescent literature, juvenile literature, children's literature, among a number of other names, describe texts that bridge the gap between children's literature and adult literature. Owing to the negative connotations of the words 
adolescentsand teens, most experts today prefer youngadult literature. Among the characteristics of this literature are:the protagonist is a teenager and events revolve around his/her struggle to resolve conflict, and the story, which is usually short,( closer to 200 pages) is told from the viewpoint and in the voice of a young adult. A happy ending is rare in these stories and in them parents are noticeably absent or at odds with young adults. In that literature most of the themes deal with coming-of-age issues like maturity, sexuality, relationships, anddrugs. Young Adult Literature is written by and for young adults and marketed to the young adult audience("Trends and Issues in Young Adult Literature"). Toni Morrison is one of the first writers who show interest in adolescence. The Bluest Eye is an early example of such a concern. What characterizes her depiction of the young adult world is her reliance on her African-American heritage.

In The Bluest Eye Morrisondepicts how a female teenager's self is crushed as she strugglesto gain psychic wholeness in a hostile world. The reason behind the adolescent's fragile identity has to do with the terrible reality that the marginal self has to cope with to become a true human being outside the Western discourse. The two main aspects which make the disintegration of the female teenager's subjectivity more significant than that of others are: the adolescent's vulnerability due to his/her gender and age, which makes him/her more prone to become a victim in adversities and the psychic disorders in one's teens which are highly serious, since they ultimately shape the future(Ramirez 75-76).

In many of her novels Morrison has reflected the impact of psychological trauma on the female teenager's selfhood. Pecola Breedlove in The Bluest Eye and Sorrow in A Mercy, are good representatives of this 
impact. In The Bluest Eye the dissociation of the female adolescent identity stems from the colonization of blacks by mainstream culture and the internalization of its standards of beauty, which engender self-hatred.The influence of psychological trauma on selfhood is determined by social oppression and power dynamics. In The Bluest EyeMorrison highlights the invisible psychic wounds of social minorities;

the traumaticeffects of oppression ....are not necessarily overtly violent or threatening to bodily well-being ...but that do violence to the soul and spirit. Social and racial minorities experience insidious trauma as a result of the cruelty inflicted by the dominant group, usually the whites. Hence, they internalize feelings of inferiority and self-contempt, which are projected onto them by the patriarchal Western discourse. Systemic racism, like other types of marginalization and social exclusion, determine the forms which the transgenerational transmission of trauma takes within the family and community. Colonized members of minority groups become oppressors themselves, reproducing the values of the hegemonic group, of which they are victims (76).

In the process of marginalization, minority individuals are turned into rejected and debased objects, which results in damaging their psyches. This process is especially dramatic when the victims are vulnerable like teenagers, especially that their subjectivity is not yet fully developed. Pecola symbolizes the difficulties that being a woman and black entail, for, like blackness, womanhood, is the Other in this societyand the dilemma of women in a patriarchal society is equal to that of blacks in a racist society. "Abjection erodes their self-esteem and provokes self-loathing, destabilizing them emotionally. Trauma, self-contempt and ostracism, at a 
critical stage of the identity formation, might make their victims cross the border from sanity into insanity"(77).

Pecola Breedlove exemplifies the pervasive negative effects that internalized racial prejudice has on black children, and how it may lead to insanity. For her, as for other members of her community, color determines her identity: her feeling of inferiority and self-disgust. She believes that beauty and self-worth are associated with whiteness and, therefore, she cannot construct a positive self-image. Teenagers highly estimate the family and society's gaze. Pecola can only view herself in the mirror of other people's Look. She remains invisible to herself until she can hallucinate a self. In short, she embodies the black individual's history of oppression and exclusion (78-79).

Pecola is condemned into a perpetual conversation with herself because it is fragmented. This is partly attributed to the lack of love inside her family. Pecola's parents, Cholly and Pauline, do not give their daughter the love and concern needed to create "a positive sense of self-worth" ( Ho 5).Furthermore, being black and poor, they have accepted the idea that they are ugly:

The Breedloves did not live in a storefront because they were having temporary difficulty adjusting to the cutbacks at the plant. They lived there because they were poor and black, and they stayed there because they believed they were ugly. Although their Poverty was traditional and stultifying, it was not unique. But their ugliness was unique. No one could have convinced them that they were not relentlessly and aggressively ugly. Except for the father, Cholly, whose ugliness (the result of despair, dissipation, and violence directed toward petty things and weak people) 
was behavior, the rest of the family... Mrs.Breedlove, Sammy Breedlove, and Pecola Breedlove wore their ugliness, put it on, so to speak, although it did not belong to them. (TBE 38)

In accepting this false belief, Cholly and Pauline, have deprived themselves of their own self-value on one hand and internalized the white standards of beauty on the other. Hence, their constant fighting and hatred (Ho 8).Cholly's unemployment makes his situation worse and leads him ultimately to drinking. The birth of his two children, Sammy and Pecola, makes him impotent as he himself is an orphan and knows not how to deal with children. Feeling love towards them, he is unable to express it properly (9). Therefore, one day in 1941, he gets home drunk and finding Pecola alone, she makes a gesture which reminds him of his first encounter with his wife, he rapes her for the first time, an action which leads to her ultimate madness. While her mother, Pauline Breedlove, rejects her as a result of her own self-contempt, which she acquires in her role as an 'ideal servant'. She does not show her children much attention or love. Pauline has always despised her daughter. She is nice and kind with the children of the Fishers, the white family for whom she works. The white girl calls her Polly, while her own daughter addresses her as Mrs. Breedlove. Pauline feels ashamed of her child and abuses her. She madly attacks Pecola when the girl accidentally spills a blueberry pie at the Fishers' daughter. Many psychologists emphasize the importance of the mother's Lookfor the development of the child's subjectivity.The mother's Look greatly contributes to the child's evolving self-concept and Pecola is exposed, from her birth, to a shaming and condemning gaze. As a mother Pauline utterly fails when she heeds not Pecola's account of the first time her father rapes 
her. Her disbelief prevents her from protecting her daughter, who will be a victim of further sexual assault( Ramirez78).

Following her marriage to Cholly, Pauline moves to the north, Ohio, where she feels uprooted and lonely. Therefore, she finds some consolation by attending the movies from where she learns to internalize the white standards of romantic love and physical beauty, "the most destructive ideas in the history of human thought. Both originated in envy, thrived in insecurity, and ended in disillusion" (TBE 122) which later characterize her relationship with her husband and her daughter. The education she received from movies made her return home difficult, for "she was never able...to look at a face and not assign it some category in the scale of absolute beauty, and the scale was one she absorbed in full from the silver screen" (TBE97). Accordingly, when she looks at her own daughter, she places her at the bottom of the beauty scale. "I knowed she was ugly. Head full of pretty hair, but Lord she was ugly" (TBE126). Since she judges people according to white standards of beauty, she offers disgust rather than tenderness to her ugly daughter (Ho 9).

Additionally, society increasesPecola'sfeeling of worthlessness: at school a group of black boys harass her; a brown boy bullies her while his mother throws her out of her house; a white shopkeeper "looks" at her but does not "see" her; but the most appalling thing is that when she reaches womanhood at the age of twelve, her father rapes her twice and impregnates her. Then a crazy priest uses her to poison the dog of his landlady for an exchange of blue eyes, which only she sees(4) She finally retreats to her private imaginary world talking to herself in the mirror."She is not seen by herself until she hallucinates a self",comments Morrison in the "Afterword." 
Toni Morrison's writing style and a number of her prevalent themes to date are set forth in The Bluest Eye. Some of Morrison's recurrent themes include reconstructing history, heritage, and personal identity, beauty, love,motherhood, and the family in relation to the community."In terms of her style, the ease and appropriateness with which Morrison, employs African-American as well as Midwestern American vernacular speech ...allow her to present the particularities of these specific cultural speech patterns without ...suggesting that the language becomes a type of linguistic violation...[So] in The Bluest Eye and in subsequent novels...she has reconstructed the language of a place"(Jimoh).

Part of the attraction of that place involves not only language, but folklore as well. Pecola'sacquiring of blue eyes through magic practiced by a lunatic priestreflects the belief of African Americans in magic. Barbara $\mathrm{J}$. Wilcotsin "Fiction and Folklore: The Novels of Toni Morrison" attributes Pecola's belief in magic to African-American folklore. She emphasizes that Pecola's belief in magic has its origin in African as well as European traditions. She explains that African people, such as the African tribe of Yoruba, regard magicas the equivalent to the deus ex machina in European fairy tales. "In Western African tales, conjurers alternately reward or thwart protagonists' attempts at self-fulfillment and acceptance in society. In Pecola's case, her isolation and madness...becomes, in West African folkloric tradition, an expected outcome." Soaphead Church, the priest she thinks grant her her wish, and people's belief in him, are described in these terms:

Singly[people]...found their way to his door, wrapped each in a shroud stitched with anger, yearning, pride, vengeance, loneliness, misery, defeat, and hunger. They asked for the simplest of things: love, health, and money. 
Make him love me. Tell me what this dream means...keep my baby's ghost off the stove. To all these requests he addressed himself. His practice was to do what he was bid. (TBE 172)

Actually some even think of Pecola's life as a blues song( Moses 122). Singing the blues is one of the most distinctive features of African American heritage. Morrison tried to make the music in her narrative more functional than it really seemed. In The Bluest Eye, she wanted "to do what the music did for blacks, what we used to be able to do with each other in private and in that civilization that existed underneath the white civilization"(qtd.in Moses623). The novel is similar to a blues song in the matter of its content which is that of poverty, misery and suffering. Being unable to sing her song, Pecola daily lives the blues. The novel's connection to the blues is suggested earlier in the title. By replacing the "eye" by "I"the novel could also mean "the gloomiest self" ( Spies 121).

The novel follows a pattern traditional in blues songs: an initial loss, then an overcoming of grief by moving on. Between loss and moving on, the novel is full of cultural wisdom. Claudia, Pecola's friend and the adolescent story teller, achieves catharsis at the expense of Pecola's experiences. In traditional blues songs, the singer is the subject, the I who tells his story. In The Bluest Eye, it is Claudia who narrates Pecola's story. Except for a few lines, Pecola remains silent within Claudia's narrative. Therefore, it is Claudia who represents the 'I' of the blues subject and Pecola as the abject on which the blues of the community is inscribed( Moses 623). Rather than singing Pecola's blues, Calaudia "sings" the community's blues"( 624). Pecola represents the community's scapegoat and the catharsis which is an indispensible part of the blues, is not hers. Hence, the story is that of Pecola,and not Pecola's story(Spies 121). 
"Caludia bears witness, through the oral tradition of testifying, to the community's lack of self-love and its transference of this lack onto the abject body of Pecola" (Moses 624)."All of our waste which we dumped on her and which she absorbed. And all of our beauty, which was hers first and which she gave to us. All of us-all who knew her-felt so wholesome after we cleaned ourselves on her" (TBE159), thinks Claudia.

Another particularly noteworthy aspect of Morrison's first novel as well as of later books is her perceptive, insider narrative voice or voices. Among the three narrators that Morrison employs in The Bluest Eye, Claudia MacTeer, a precocious youth of intuitive wisdom, is her most compelling, as she presents her own view of the events of 1940-1941 in Lorain, Ohio(Jimoh). Unlike Pecola, Claudia, who has a loving and caring family and much self-confidence, rejects the white standards of beauty her society cherishes, "Adults, older girls, shops, magazines, newspapers,window signs-all the world had agreed that a blue-eyed, yellow-haired, pink-skinned doll was what every girl child treasured...I destroyed white baby dolls", (TBE22).

The novel is a bildungsroman, told by Pecola'sfriends, Claudia and Frieda MacTeer,who witness the tragic events of the 1941 in Ohio.Theynot only defend Pecola against society, help her understand the changes taking place in her body, pray that Pecola's baby will not die, they, more importantly, orchestrate breaking the silence related to the violation of their friend. "Quiet as it's kept, there were no marigolds in the fall of 1941", announces the novel's opening through Claudia. In the "Afterword", Toni Morrison explained the goal behind their story, not having the appropriate vocabulary to understand what happened to their friend in 1941, they 
thought by looking back at that time (as adults now) they would understand:

Thus, the openingprovides the stroke that announces something more than a secret shared, but a silence broken, a void filled, an unspeakable thing spoken at last. And it draws the connection between a minor destabilization in seasonal flora and the insignificant destruction of a black girl...both phenomena are earthshaking depositories of information they spend that whole year of childhood...trying to fathom, and cannot. If they have any success, it will be in transforming the problem of fathomingto the presumably adult reader...if [such]... then the book can be seen to open with its close: a speculation on the disruption of "nature" as being a social disruption with tragic individual consequences in which the reader, as part of the population of the text, is implicated. (TBE214, italics mine )

So the violation of nature symbolizes a human violation with tragic consequences suffered by Pecola, a thing Toni Morrison hopes will be understood and felt by the reader.

While concerned with recording the history of her own people, Morrison deals with the impact of slavery on the black psyche as represented by the consciousness of a young girl who wishes to be up to the white standards of beauty. Though her young characters, Morrison attempts to break while shapingthe silence over the suffering and destruction of African-American teens. She has a privilege over writers of Young AdultLiterature. She, through her young adult girls, envisions the future of African-American people. Her anatomy of the past is not to suggest that its atrocities and ugliness should be forgotten and left behind. Rather she uses the past as a warning that the consequences of marginalization and 
victimization are serious, especially, for the young generation who is responsible for the future and change. She seems to imply that if the young generation is psychologically disturbed and crippled, the dawn of change or tomorrow will be late in coming if it comes at all.

\section{References}

1. Ghansah, Rachel Kaadzi."The Radical Vision of Toni Morrison". The New York Times Magazine.8 April 2015. Web. September 15, 2017.

2. Ho, Wen-ching. "In Search of a Female Self: Toni Morrison's The BluestEye and Maxine Hong Kingston's The Woman Warrior". American Studies, XVII, No.3, September 1987, 144.Web. 15 September, 2017.

3. Jimoh,AYemisi, "Toni Morrison: The Bluest Eye". AfroAmerican Studies Faculty Publication Series. 93.(2003).Web. 14 April, 2012.

4. Laflen, A. Confronting Visuality in Multi-Ethnic Women's Writing. New York :Palgrave Macmillan, 2014. Print

5. Madden, MT. "Necessary Narratives: Toni Morrison and Literary Identities."Women Studies International Forum. 18(5/6).1995. Web.6October, 2017. 
6. Morrison, Toni. The Bluest Eye. New York: Penguin Books, 1994.Print

7. .............."The Site of Memory"in Inventing the Truth: the Art and Craft of Memoir, $2^{\text {nd }}$ ed. Ed. William Zinsser. New York: Houghton Mifflin, 1995. 83-102.Web. 6 October, 2017.

8. Moses, Cat. "The Blues Aesthetics in The Bluest Eye". African American Review. Winter 33 (1999)4: 623-637.Web.10 August, 2017.

9. Ramirez, Manuela Lopez ."The Theme of the Shattered Self-in Toni Morrison's The Bluest Eye and A Mercy". Miscelánea: A Journal of English and American Studies 48 (2013): 75-91.Web. 3 August,2017.

10. Spies, Christine."Vernacular Traditions: The Use of Music in the Novels of Toni Morrison". MA thesis. Universität Trier, n.d. Web. 1 April, 2017.

11. "Trends and Issues in Young Adult Literature."N. d. Web. 16 September, 2017.

12. Wilcots, Barbara J. "Fiction and Folklore in the Novels of Toni Morrison". African American Review. 22 December 1992. Web. 3 July ,2017. 


\title{
About the Author
}

Isra HashimTaher is Assistant Professor at the Department of EnglishCollege of Arts-University of Baghdad. She has Ph. D. in American novel. She has been teaching English and American literature since 2002. She has taught three MA courses and supervised eight MA theses in the University of Baghdad.

Email: israh@coart.uobaghdad.iq

\section{المسكوت عنه في رواية توني موريسون"العين الاكثر زرقة"}

\author{
ا..م .د. اسراء هاشم طاهر \\ جامعة بغداد / كلية الآداب / قسم اللغة الانكليزية
}

\section{خلاصة البحث}

تعد توني موريسون (1931) اول امرأة امريكية من اصل افريقي تحصل على جائزة نوبل للآداب في عام 1993 ، وتفوز بجائزة البولتزار للرواية، وتعد نفسها مؤرخة للأمريكان من اصل افريقي. ولم تكن كتاباتها تمثل ادب بل كتابا مقدا مخصصا لاستكثاف الحياة الداخلية للسود. فهي تصنع التاريخ عن طريق تجاهل المعايير الاوربية و وجهة نظر الرجل الابيض حيال الامريكيين من اصل افريقي. فهي تتبنى وجهة نظر ناسها ،وتستثر تراثهم وتعبر عن ألامهم وتستخدم لهجتهم، وكأنها تكتب لجمهور اسود. وقد اسست "رواية السود" عن طريق تصوير السواد في الادب الامريكي. وعندما اختارت الكتابة عن الماضي لم تكن تحاول ان تكون واعظة كباقي الكتاب بل كانت ذات رؤية مستقبلية. وعندما اختارت كثف النقاب عن قصص، افظع من ان تروى ،كسرت الصمت من خلال مناقتة موضو عات كالاغتصاب و الزنى بالقربى ولذلك فان روايتها الاولى "العين الاكثر زرقة"يمكن ان تعد مثالا عن ادب اليافعين، وهو ادب يعنى بمشاكل موكل المر اهقين و اليافعين وتحدياتهم عند النضوج. 
تركز الرواية التي نشرت في سبعينيات القرن العشرين، ودارت احداثها في اوهايو في سبعينيات القرن العشرين على التجربة الشخصية لفتاة سوداء شابة تدعى (بيكو لابريدلف) و التي تصلي بسبب قلة جمالها وتحجيمها في عيون الاخرين- للحصول على عيون زرق، تعتقد انها ستمنحها الحب والجمال. تتتهي الرواية بهلوساتها بعد ان بغتصبها والدها ، وبعد ان تظن انه اصبح لديها عيون زرق. يحاول البحث ان يبرهن ان الكاتبة (موريسون) في"العين الاكثر زرقة "تقوم بمهنين وهما : الاسهام في ادب اليافعين بينما تؤكد على ان تحويل عرق كامل الى شياطين يبدا داخل ارق عنصر في المجتمع و هو الطفل.

الكلمات المفتاحية : موريسون، "العين الاكثر زرقة " ، التاريخ ، ادب اليافعين 